\title{
Characterization of carbonate fraction of the Atlantic bluefin tuna fin spine bone matrix for stable isotope analysis
}

\author{
Patricia Lastra Luque ${ }^{\text {Corresp., } 1}$, María Belén Sanchez-Ilárduya ${ }^{2}$, Alfredo Sarmiento ${ }^{3}$, Hilario Murua ${ }^{1}$, Haritz \\ Arrizabalaga $^{1}$ \\ 1 Marine Research Division, AZTI Tecnalia, Pasaia, Guipuzcoa, Spain \\ 2 Advanced Research Facilities (SGlker)/ X-ray Photoelectron Spectroscopy Laboratory (XPS)/Faculty of Science and Technology, University of the Basque \\ Country (UPV/EHU), Leioa, Bizcaia, Spain \\ 3 Advanced Research Facilities (Sgiker) / Coupled Multispectroscopy Singular Laboratory (Raman-LASPEA)/ Faculty of Medicine and Odontology, University \\ of the Basque Country (UPV/EHU), Leioa, Bizcaia, Spain \\ Corresponding Author: Patricia Lastra Luque \\ Email address: plastra@azti.es
}

The mineral component of fish otoliths (ear bones), which is aragonitic calcium carbonate $\left(\mathrm{CaCO}_{3}\right)$, makes this structure the preferred sample choice for measuring biological carbon and oxygen-stable isotopes in order to address fundamental questions in fish ecology and fisheries science. The main drawback is that the removal of otoliths requires sacrificing the specimen, which is particularly impractical for endangered and commercially valuable species such as Atlantic bluefin tuna (Thunnus thynnus) (ABFT). This study explores the suitability of using the first dorsal fin spine bone of ABFT as a non-lethal alternative to otolith analysis or as a complementary hard structure. The fin spines of freshly caught ABFT were collected to identify carbonate ions within the mineral matrix (i.e., hydroxyapatite) and to determine the nature of the carbonate substitution within the crystal lattice, knowledge which is crucial for correct measurement and ecological interpretation of oxygen and carbon stable isotopes of carbonates. Fin spine sections were analyzed via X-ray Photoelectron Spectroscopy (XPS), Raman Spectroscopy, and Fourier Transform InfraRed (FTIR). The XPS survey analysis showed signals of $\mathrm{Ca}, \mathrm{O}$, and P (three compositional elements that comprise hydroxyapatite). The Raman and FTIR techniques showed evidence of carbonate ions within the hydroxyapatite matrix, with the IR spectra being the most powerful for identifying the type $B$ carbonate substitution as shown by the carbonate band in the $v_{2} \mathrm{CO}_{3}{ }^{2-}$ domain at $\sim 872 \mathrm{~cm}^{-1}$. The results of this study confirmed the presence of carbonate ions within the mineral matrix of the fin spine bone of ABFT, showing the feasibility of using this calcified structure for analysis of stable isotopes. Overall, our findings will facilitate new approaches to safeguarding commercially valuable and endangered/protected fish species and will open new research avenues to improve fisheries management and species conservation strategies. 


\section{Characterization of the carbonate fraction of the 2 Atlantic bluefin tuna fin spine bone matrix for stable 3 isotope analysis}

4

5

6 7

8

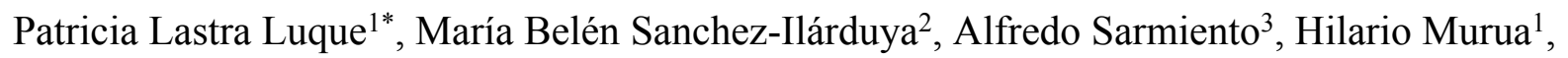
Haritz Arrizabalaga ${ }^{1}$

${ }^{1}$ AZTI Tecnalia, Marine Research Division, Herrera Kaia, Portualdea z/g E-20110 Pasaia, Gipuzkoa, Spain

${ }^{2}$ Advanced Research Facilities (SGIker), X-ray Photoelectron Spectroscopy Laboratory (XPS), Faculty of Science and Technology, University of the Basque Country (UPV/EHU), Barrio Sarriena, s/n, Leioa, Spain

${ }^{3}$ Advanced Research Facilities (Sgiker), Coupled Multispectroscopy Singular Laboratory (Raman-LASPEA), Faculty of Medicine and Odontology, University of the Basque Country (UPV/EHU), Barrio Sarriena, s/n, Leioa, Spain.

Corresponding Author:

Patricia Lastra Luque ${ }^{1}$

Herrera Kaia, Portualdea z/g E-20110 Pasaia, Gipuzkoa, Spain

Email address: plastra@azti.es 


\section{Abstract}

38 The mineral component of fish otoliths (ear bones), which is aragonitic calcium carbonate $\left(\mathrm{CaCO}_{3}\right)$, makes this structure the preferred sample choice for measuring biological carbon and oxygen-stable isotopes in order to address fundamental questions in fish ecology and fisheries science. The main drawback is that the removal of otoliths requires sacrificing the specimen, which is particularly impractical for endangered and commercially valuable species such as Atlantic bluefin tuna (Thunnus thynnus) (ABFT). This study explores the suitability of using the first dorsal fin spine bone of ABFT as a non-lethal alternative to otolith analysis or as a complementary hard structure. The fin spines of freshly caught ABFT were collected to identify carbonate ions within the mineral matrix (i.e., hydroxyapatite) and to determine the nature of the carbonate substitution within the crystal lattice, knowledge which is crucial for correct measurement and ecological interpretation of oxygen and carbon stable isotopes of carbonates. Fin spine sections were analyzed via X-ray Photoelectron Spectroscopy (XPS), Raman Spectroscopy, and Fourier Transform InfraRed (FTIR). The XPS survey analysis showed signals of $\mathrm{Ca}, \mathrm{O}$, and $\mathrm{P}$ (three compositional elements that comprise hydroxyapatite). The Raman and FTIR techniques showed evidence of carbonate ions within the hydroxyapatite matrix, with the the carbonate band in the $v_{2} \mathrm{CO}_{3}{ }^{2-}$ domain at $\sim 872 \mathrm{~cm}^{-1}$. The results of this study confirmed the presence of carbonate ions within the mineral matrix of the fin spine bone of ABFT, showing the feasibility of using this calcified structure for analysis of stable isotopes. Overall, our findings will facilitate new approaches to safeguarding commercially valuable and endangered/protected fish species and will open new research avenues to improve fisheries management and species conservation strategies.

\section{Introduction}

Use of otoliths (ear bones) found in teleost fish species is preferred by fishery biologists as they provide time-calibrated archives of isotopic information $\left(\delta^{13} \mathrm{C}\right.$ and $\left.\delta^{18} \mathrm{O}\right)$ within the mineral matrix that can be used to address fundamental questions in fish ecology and fisheries science related to migration, habitat use (Campana, 2005; Elsdon et al., 2008; McMahon, Berumen \& Thorrold, 2012) and stock structure (Patterson, McBride \& Julien, 2004). The premise of this approach is that as these biogenic structures grow, they precipitate material (e.g., stable isotopes) that are naturally incorporated into their mineral matrix (aragonite, $\mathrm{CaCO}_{3}$ ) in direct proportion to the concentration at which they occur in their habitat. As the fish grow, they record the chemistry of their natural habitat as well as other environmental parameters (e.g., temperature, salinity) (Lin et al., 2007; Miller, 2009), thereby linking the hard structure chronology with the chemical record of the fish's life. This enables a retrospective description to be produced of the environmental history of individual fish over ecological time scales (e.g., Walther \& Limburg, 2012; Rooker et al., 2014). However, otolith removal from live specimens requires specimen sacrifice, which may be forbidden in the case of endangered and /or protected fish species. In 
77 addition, it is not practical for commercially valuable species such as Atlantic bluefin tuna since 78 it greatly affects the appearance of a fish, diminishing its market value. Alternative hard tissues 79 such as the first dorsal fin spine bone may provide valuable and complementary chemical 80 information, so sampling these tissues represents a non-lethal, minimally invasive sampling 81 method (Zymonas \& McMahon, 2006). This makes using fin spines particularly attractive for 82 fish species that cannot be sacrificed for their otoliths such as endangered (threatened) fish or 83 those of management concern (e.g. protected, or commercially valuable whole fish). The term 84 "fin spines" is applied to the anterior-most structural components of fins that are unsegmented, 85 rigid, and more calcified than the soft, segmented "fin rays" (Tzadik et al., 2017). Similar to 86 other bones of the endoskeleton, fin spines are assumed to be composed of three main composed of hydroxyapatite (HA), and water (10\%wt.) (e.g., Koch, 2007; Rey et al., 2009; Ugarte et al., 2011). As such, the mineral component of bone, Hydroxyapatite $\left(\mathrm{Ca}_{10}\left(\mathrm{PO}_{4}\right)_{6}(\mathrm{OH})_{2}\right)$, is a type of calcium phosphate apatite, which is deposited onto collagen fibrils, providing strength to the bone structure and also serving as an ion reservoir (LeGeros, 1981). In biological tissues, this mineral matrix is complex, rarely stoichiometric, and usually calcium-deficient. It accommodates chemical substitution relatively easily, incorporating a wide variety of relatively small amounts of other substituent atoms or groups taken up from the surrounding body fluids during bone metabolism (Mathew \& Tagaki, 2001; Matsunaga et al., 2010; Figueiredo, Gamelas \& Martins, 2012). As such, the HA structure in bone may contain carbonate $\mathrm{CO}_{3}{ }^{2-}$ ions that substitute either for phosphate (B-type HA) or hydroxyl (A type-HA) groups within the crystal lattice (LeGeros, 1991, Rey et al., 2009). Although the B-type is the preferential $\mathrm{CO}_{3}{ }^{2-}$ substitution found in the bone of a variety of species (Landi et al., 2003; Murugan, Ramakrishna \& Panduranga, 2006), this substitution remains unexplored specifically in the fin spine bone of teleost species. Although these levels of substitution are small, it has been established that these elements are associated with the properties of biological apatite and play a major role in the biochemistry of bone (Ibrahim, Mostafa \& Korowash, 2011). However, our lack of understanding of metabolic pathways, routes of ion uptake, and differential abilities of structures to incorporate elements and stable isotopes should be taken into consideration when using these structures (Campana, 1999). The general assumption that the mineral content of fin spine bone (i.e. hydroxyapatite) is identical to other bones needs further exploration, and a thorough understanding of species-specific skeletal biology may make interpretation of these isotopic records possible. For correct measurement and reliable biological interpretation of the isotopic signal of carbonates contained in the fin spine bone, the required first step is to assess whether or not this carbonate substitution is regular within the HA matrix. The main goal of this study is to characterize the carbonate fraction in the fin spine bone and determine the level and nature of the carbonate substitution within the calcium phosphate apatite, which is the main mineral component of the fin spine bone. This is critical to analyzing and interpreting the carbon and oxygen stable isotope signature retained within the mineral fraction of the fin spine bone. We used Fourier transform Infrared (FTIR) and Raman spectroscopy for the bulk analysis and 
117 complemented this investigation using X-Ray photoelectron spectroscopy (XPS) as a highly

118 sensitive surface technique.

119

120

Materials \& Methods

121

122

123

Sample collection

124

In this study, the first spiniform ray of the first dorsal fin (fin spine hereafter) was collected from

125 fresh Atlantic bluefin tuna caught by commercial bait boats in the Bay of Biscay (North-east

126

127

128

129 Atlantic Ocean). The sample set comprised four individual fin spine samples collected from young specimens of $81,101,114$, and $128 \mathrm{~cm}$ straight fork lengths (SFL).

130

131

132

133

134

135

136

137

138

139

140

141

142

143

144

145

146

147

148

149

150

151

152

153

\section{Fin spine bone preparation}

Fin spine preparation and sectioning procedures were performed following the procedures described by Luque et al., (2014). Once the fin spine was removed, the remaining skin tissue was carefully removed with a sharp scalpel, avoiding any damage to the surface of the base of the fin spine. Then, before sectioning, individual fin spines were washed with Milli-Q water and air dried at room temperature. A cross-section of $\sim 1.5 \mathrm{~mm}$ thickness was sectioned at a point 1.5 times the condyle base width (1.5Dmax) (Fig. 1A, B) with an Isomet low-speed diamond saw (Buehler, Lake Bluff, Illinois, USA). Additionally, fin spine sections underwent an extra cleaning cycle, by placing them into individual $1.5 \mathrm{~mL}$ vials with ultrapure deionized water (Milli-Q, 18.2 Mohm.cm-3) and using an ultrasonic water bath for $10 \mathrm{~min}$ to remove excess organic tissue. Finally, the samples were rinsed again with ultra-pure water and placed in new vials, then allowed to dry in a class 100 laminar-flow hood for $48 \mathrm{~h}$.

\section{X-ray Photoelectron Spectroscopy (XPS)}

XPS experiments were recorded with a SPECS (Berlin, Germany) system equipped with a Phoibos 150 1D-DLD analyzer and using monochromatic AlKa radiation $(1486.7 \mathrm{eV}, 300 \mathrm{~W}, 13$ $\mathrm{kV}$ ). Spectra were acquired in the constant pass energy mode at a binding energy (BE) of $80 \mathrm{eV}$ for survey spectra (step energy $1 \mathrm{eV}$, dwell time $0.1 \mathrm{~s}$ ) and $30 \mathrm{eV}$ for high-resolution spectra (step energy $0.1 \mathrm{eV}$, dwell time $0.1 \mathrm{~s}$ ) with an electron take-off angle of $90^{\circ}$. The spectrometer had previously been calibrated by using the $\mathrm{Ag}(3 \mathrm{~d} 5 / 2)$ line at $368.26 \mathrm{eV}$. The binding energy scales for the samples were corrected by setting the $\mathrm{C}(1 \mathrm{~s})$ peak of the adventitious carbon to $284.6 \mathrm{eV}$ (other peaks were corrected accordingly) (Wagner et al., 1979). The spectra were fitted with the Casa XPS 2.3.16 software, which models the Gauss-Lorentzian contributions, after background subtraction (Shirley). Concentration values were calculated using the atomic sensitivity factors from Scofield cross-sections and considering the instrumental transmission function and corrections due to differences in the inelastic mean free path.

154

155

\section{Raman Spectroscopy}


156 The Raman measurements were conducted with a Renishaw In Via Raman spectrometer, linked 157 to a Leica DMLM microscope. The spectra were acquired with a Leica 50x N Plan (0.75

158 aperture) lens that yields a spatial resolution of two microns. The instrument used a diode laser 159 exciting at a wavelength of $785 \mathrm{~nm}$ (diode laser, Torsana) with a power at the source of $350 \mathrm{~mW}$, 160 the maximum power at the sample being $150 \mathrm{~mW}$. The Raman scattered light was dispersed with 161 a grating of 1200 lines $/ \mathrm{mm}$ and was detected by a Peltier cooled charge coupled device (CCD) 162 detector of $576 \times 384$ pixels, with a spectral resolution of $1 \mathrm{~cm}^{-1}$. In all the measurements, the 163 power of the laser was reduced using neutral density filters to avoid photo-decomposition of the 164 samples (burning). For each spectrum, the CCD detector was open for 20 seconds, and five scans 165 were made at $10 \%$ of the maximum power of the $785 \mathrm{~nm}$ laser in the spectral window from 150 $166 \mathrm{~cm}^{-1}$ to $3200 \mathrm{~cm}^{-1}$. The operation of the equipment was fully software-controlled using WiRE 3.4 167 software.

168

169

170

171

172

173 174

175

176

177

178

179

180

181

182

183

184

185

186

187

188

189

190

191

192

193

194

\section{Fourier Transform Infrared Spectroscopy (FTIR)}

All infrared spectra were measured in transmittance mode on a Jasco 4200 spectrometer by grinding samples with potassium bromide $(\mathrm{KBr})$ powder and then pressing them into a disk. Spectra were acquired over the range 4000 to $400 \mathrm{~cm}^{-1}$. Each spectrum represented the average of 40 scans at a resolution of $4 \mathrm{~cm}^{-1}$, in order to provide a good signal to noise ratio. The instrument was controlled by Jasco software that also allowed for the processing of the results.

\section{Analysis of spectral data from Raman and FTIR Spectroscopy}

The intensities of the amide I, phosphate and carbonate bands were calculated from IR and Raman spectra by being the baseline for each peak linearly corrected using the same wavenumber limits (see Table 1). These spectral features were used to estimate the mineral/matrix ratio, that is the proportion of the mineral (phosphate band) compared to the organic content (in this case Amide I band) and the level of carbonate substitution, i.e., the carbonate/phosphate ratio. Additionally, crystallinity was determined from the inverse of the full width at half-maximum (FWHM) of the v1 phosphate peak in the Raman spectra (Turunen et al., 2011).

\section{Results \& Discussion}

\section{XPS}

Elemental composition and functional group identification of fin spine samples of bluefin tuna were accomplished by XPS analysis, thereby obtaining survey scans and high-resolution XPS spectra of the detected elements. Figure 2 shows a typical XPS wide spectrum from the bluefin tuna fin spine sample showing the signals of carbon $(\mathrm{C}(1 \mathrm{~s})(284.6 \mathrm{eV}))$, nitrogen $(\mathrm{N}(1 \mathrm{~s})$ $(\sim 399 \mathrm{eV}))$, calcium $(\mathrm{Ca}(2 \mathrm{p})(\sim 347 \mathrm{eV}))$, oxygen $(\mathrm{O}(1 \mathrm{~s})(\sim 531 \mathrm{eV}))$, and phosphorous $(\mathrm{P}(2 \mathrm{p})$ $(\sim 133 \mathrm{eV}))$ peaks. The last three comprise the compositional elements of the typical 
195 hydroxyapatite $\left(\mathrm{Ca}_{10}\left(\mathrm{PO}_{4}\right)_{6}(\mathrm{OH})_{2}\right)$. Nitrogen was not detected in sample BFT2 while for BFT1 it

196

197

198

199

200

201

202

203

204

205

206

207

208

209

210

211

212

213

214

215

216

217

218

219

220

221

222

223

224

225

226

227

228

229

230

231

232

233

234

was found close to background noise, with its atomic concentration being around $1.4 \%$.

Phosphorous was not detected in either of the two bluefin tuna fin spine samples. Additionally, the high-resolution XPS spectra of $\mathrm{C}, \mathrm{O}, \mathrm{Ca}, \mathrm{N}$, and $\mathrm{P}$ were analysed in all tuna fin spine samples and their relative atomic concentrations are given in Table 2. Using sample BFT3 as an example, the high-resolution $\mathrm{Ca}(2 \mathrm{p})$ core spectrum splits into two peaks identified as $\mathrm{Ca}\left(2 \mathrm{p}_{3 / 2}\right)$ and $\mathrm{Ca}\left(2 \mathrm{p}_{1 / 2}\right)$ due to spin-orbit coupling. The main peak $\mathrm{Ca}\left(2 \mathrm{p}_{3 / 2}\right)$ can be observed at $346.6 \mathrm{eV}$, while $\mathrm{Ca}\left(2 \mathrm{p}_{1 / 2}\right)$ appears at $350.2 \mathrm{eV}$. In the same way, the $\mathrm{P}(2 \mathrm{p})$ core spectrum splits into two peaks, the main peak $\mathrm{P}\left(2 \mathrm{p}_{3 / 2}\right.$ at $132.4 \mathrm{eV}$ and $\mathrm{P}\left(2 \mathrm{p}_{1 / 2}\right)$ at $133.4 \mathrm{eV}$, in good agreement with phosphate type compounds (Lu et al., 2000; Rey et al., 2009). Meanwhile, the high-resolution $\mathrm{O}(1 \mathrm{~s})$ spectrum was fitted with only one component detected at $530.8 \mathrm{eV}$. Similar spectra for $\mathrm{Ca}(2 \mathrm{p})$ and $\mathrm{O}(1 \mathrm{~s})$ were obtained from samples BFT1, BFT2 and BFT4 and for P(2p) from sample BFT4. Two contributions could be distinguished for the high-resolution spectra of C(1s) at $284.6 \mathrm{eV}$ (main peak) and $287.5 \mathrm{eV}$. The first one may have been associated with the $\mathrm{C}-\mathrm{C} / \mathrm{C}-\mathrm{H}$ bonding. The other peak at $287.5 \mathrm{eV}$ can be attributed to a bonding between carbon and oxygen. The C(1s) spectra observed for the other samples were quite similar, with the main contribution at $284.6 \mathrm{eV}$. Nitrogen coming from the collagen protein source of bone was also detected in three fin spine samples at binding energies around $399 \mathrm{eV}$. Regarding composition, all fin tuna spine samples showed high levels of carbon. Overall, the presence of carbon and nitrogen and the high proportion of oxygen $(\mathrm{O} / \mathrm{Ca}$ and $\mathrm{O} / \mathrm{P}$ ratios were higher than expected in hydroxyapatite) in all tuna fin spines analyzed in comparison with the synthetic HA ( $\mathrm{Lu}$ et al., 2000) is certainly evidence of the presence of collagen Type I, an organic matrix that makes up the protein component of bone and is assimilated from the carbon and nitrogen contained in the protein constituents of a consumer's diet (Koch, 2007; Rey et al., 2009). Because of the high amount of carbon detected due to the organic matrix of the fin spine bone $(>80 \%$ in $\%$ At rel. in samples BFT1 and BFT2, and $\sim 60 \%$ in BFT3 and BFT4), and considering that XPS is a surface-sensitive technique, the relative atomic percentages of the $\mathrm{HA}$ elements such as $\mathrm{Ca}$ and $\mathrm{P}$ were quite low, $5.9 \%$ and $4 \%$, respectively, in the case of BFT3. Moreover, Ca and P concentrations were still lower or not detected in the other three samples, as can be seen in Table 2.

Based on the concentrations found for $\mathrm{Ca}$ and $\mathrm{P}$, a stoichiometric correspondence to synthetic HA Ca $5\left(\mathrm{PO}_{4}\right)_{3}(\mathrm{OH})$ can be concluded. For samples BFT3 and 4, the observed $\mathrm{Ca} / \mathrm{P}$ ratios were 1.50 and 1.53, respectively, close to the nominal value of 1.67 in hydroxyapatite. These slightly low values for the $\mathrm{Ca} / \mathrm{P}$ ratio have previously been reported (Lu et al., 2000). Additionally, carbonate is commonly found in biological minerals (LeGeros, 1981) and is a basic component of bone that might interfere with the biological interpretation of the data, particularly important for isotopic signals. In the present study, the presence of carbonate-type carbon could not be demonstrated by XPS in any of the fin spine samples. This was probably due to the high amount of carbon from the organic fraction that prevented detection of the low contribution of the carbonate in the $\mathrm{C}(1 \mathrm{~s})$ spectrum, referenced at around $289 \mathrm{eV}$ (Liu et al., 2018). Future work should be devoted to pre-treating the fin spine bone samples with chemicals (e.g., hydrazine)

Peer] reviewing PDF | (2018:12:33216:2:1:NEW 15 May 2019) 
235

236

237

238

239

240

241

242

243

244

245

246

247

248

249

250

251

252

253

254

255

256

257

258

259

260

261

262

263

264

265

266

267

268

269

270

271

272

273

274

commonly used for removing organic material and/or contamination, in order to eliminate competing sources of $\mathrm{C}$ and $\mathrm{O}$ stable isotopes associated with organic material and secondary carbonates (Snoeck \& Pellegrini, 2015; Pellegrini \& Snoeck, 2016).

\section{Raman and FTIR spectroscopy}

Mineralogical and compositional analysis of the fin spine bone samples was also performed by means of Raman and FTIR spectroscopy. Both techniques revealed that the spectra were very similar to the spectrum of human bone (Fig. 3) confirming that the mineral fraction of tuna fin spine bone mainly consisted of hydroxyapatite. Overall, the most intense bands arise from the mineral fraction, in accordance with its larger proportion in the composite. Most of the absorptions from phosphate vibrations were clearly observed in the spectra of fin spine. Mineral bands were more conspicuous in Raman spectra than in IR spectra, whereas organic signatures appeared stronger in IR spectra. Relative intensities were slightly different, but most matrices were distinguished in both types of spectra. Thus, detailed spectral assignments for a fin spine bone included vibrational modes for phosphate, carbonate and the organic matrix bands of the amides I, II, III and C-H stretch (Table 3). The main differences were found in the phenylalanine band that is weak in the Raman spectrum $\left(1004-1005 \mathrm{~cm}^{-1}\right)$ or absent in the IR spectrum, whereas the amide II in the IR spectrum $\left(1540-1580 \mathrm{~cm}^{-1}\right)$ was absent in the Raman spectrum (Table 3). In addition, Table 4 displays the main compositional parameters for each fin spine sample obtained from peak intensities in the IR and Raman spectra. The mineral/matrix ratio obtained in the IR spectra seemed to show higher values in larger specimens (i.e., in body size) whereas no clear pattern was observed in the Raman spectra. Considering that the number of analysed specimens was too low to carry out comparative and correlation analysis, the observed trends should be taken with caution. Turunen and colleagues (2011) stated that this ratio describes the degree of mineralization in the bone and average increases during maturation. As this is beyond the scope of this exploratory study, a deeper quantitative study using a larger sample size including immature and mature individuals is certainly necessary to confirm this.

FTIR spectra were also very useful in identifying carbonate $\left(\mathrm{CO}_{3}{ }^{2-}\right)$ substitution in the mineral fraction of the bluefin tuna fin spine bone. As is widely known, the $\mathrm{CO}_{3}{ }^{2-}$ ion can be allocated within the HA lattice at the hydroxide (type A) or at the phosphate (type B) positions, and these different structural positions result in different IR features. Thus, the type A carbonate, commonly has a doublet band (i.e., at 1545 and $1450 \mathrm{~cm}^{-1}$ ) that corresponds to the asymmetric stretching vibration $\left(v_{3}\right)$ and a singlet band at $880 \mathrm{~cm}^{-1}$ that represents an out-of-plane bending vibration $\left(v_{2}\right)$. Type $\mathrm{B}$ shows the strongest IR bands of the $\mathrm{CO}_{3}{ }^{2-}$ ion at about 1455,1410 and $875 \mathrm{~cm}^{-1}$ (Turunen et al., 2011; Fleet, 2015). This study showed that in the bluefin tuna fin spine bone, the carbonate ions originated in a band at $872 \mathrm{~cm}^{-1}$ which was assigned to the $v_{2}$ bending vibration (Fig. 4). These findings are certainly in line with what has been identified in biological apatites as the band characteristic of type B carbonates (Figueiredo, Gamelas \& Martins, 2012). As a result of that, it was verified that the bluefin tuna fin spine bone resembled type $B$ 
275 carbonates. Moreover, the $v_{3}$ mode $(\sim 1454, \sim 1416)$ was overlapped by strong organic absorption

276 bands. This finding should be taken with caution as it may lead to misinterpretations of bone

277 samples (Termine \& Lundy, 1973). In the present study, the type B carbonate substitution was

278 not as clearly observed in the Raman spectra as in the IR spectra. The sharpest band at $1070 \mathrm{~cm}^{-1}$

$279\left(v_{1} \mathrm{CO}_{3}^{2-}\right)$ was very close to a component of a phosphate band at $1076 \mathrm{~cm}-1\left(v_{3} \mathrm{PO}_{4}{ }^{3-}\right)$ which is

280 commonly overlapped with the band at $1110 \mathrm{~cm}-1$ due to the anionic substitution of $\mathrm{HPO}_{4}{ }^{2-}$

281 (acidic phosphates), very likely leading to misinterpretation of the spectra. The

282 carbonate/phosphate ratio seems to represent different phenomena in each analytical technique.

283 In the present study, the carbonate/phosphate ratios estimated from the Raman spectra were

284 similar for the three individual bluefin tuna fin spine samples (mean 0,101 $\pm 0,008 \mathrm{SD}$ ).

285

However, in the IR spectra, this ratio was slightly higher in the smallest and youngest specimen,

286 BFT3 (81 cm SFL, aged two years old) (Table 4). Nevertheless, this result should be treated

287

288

289

290

291

292

293

294

295

296

297

298

299

300

301

302

303

304

305

306

307

308

309

310

311

312

313

314

cautiously as we only analyzed fin spine samples from juvenile tuna that were three years old and assumed to be immature. This parameter seems to be a good indicator of the bone turnover and remodeling activity of bone (Isaksson et al., 2010), which remarkably occurs at older ages (Luque et al., 2014) and in mature bluefin tunas, and is linked to the physiology of this fish in relation to its feeding, reproduction, migrating and growing characteristics (Santamaria et al., 2015). In addition, the crystallinity index was similar for BFT1 $(128 \mathrm{~cm}$ SFL), BFT2 $(114 \mathrm{~cm}$ SFL), and BFT4 (101 cm SFL) with values of $0.058,0.061$, and 0.056 , respectively (mean $0.058 \pm 0.03 \mathrm{SD}$ ) which indicate a similar maturation state, as expected, considering that the three fin spines were collected from immature juvenile bluefin tuna that were three years old. Nevertheless, it should be considered that such parameters (i.e. mineral maturity and crystallinity) depend on several factors, not only age, but also nutrition and health condition (Figueiredo, Gamelas \& Martins, 2012). Since it was beyond the scope of the present study, we suggest further spectroscopy analysis using larger sample sizes and including specimens of different maturity stages to confirm whether spectroscopic data may provide a measure of the maturity of the crystal.

\section{Conclusions}

The major contribution of this study is the confirmation that the mineral matrix (i.e., the apatite calcium phosphate) of fin spine bone regularly showed carbonate ions that substitute for phosphate (B-type) as carbonate ions were detected within all the ABFT fin spines analyzed. As such, these findings, which are generalizable to other fish species, will allow analysis of the carbon and oxygen stable isotope within the mineral matrix, providing important ecological information on the environmental histories of fish, including stock mixing, movement and dispersal patterns etc. in areas where geographic differences in water chemistry exist. The use of fin spines is advantageous as a non-lethal, minimally invasive sampling method. This makes using fin spines particularly promising for fish species that cannot be sacrificed for their otoliths, such as endangered species (i.e., rare or threatened species) or those of management concern

Peer) reviewing PDF | (2018:12:33216:2:1:NEW 15 May 2019) 
315 (such as stock, protected, or commercially valuable whole fish), which include ABFT, opening 316 new research avenues to improve fisheries management and species conservation strategies.

317 Regarding analytical techniques, Raman and FTIR seem to be more powerful than XPS in 318 providing relevant information on the carbonate environment and its preferential substitution 319 within the HA lattice. The results indicate that caution is required when performing surface 320 analysis as other skeletal components, such as organic matter, probably affect the surface 321 detection of inorganic carbon from carbonate impurities, leading to misinterpretation of 322 structure/function relationships. When studying the fin spine bone mineral fraction, it is

323

324

325

326

327

328

329

330

331

332

333

334

335

336

337

338

339

340

341

342

343

344

345

346

347

348

349

350

351

352

353

354

recommended to remove the organic component to avoid any misdetection of components of interest.

\section{Acknowledgements}

The fin spine samples used in this work were collected by AZTI under the provision of the ICCAT Atlantic Wide Research Program for Bluefin Tuna (GBYP). The contents of the paper do not necessarily reflect the point of view of ICCAT or of the other funders. The manuscript benefited from helpful discussions with and technical support from Dr. Gorka Bidegain, Juan Carlos Raposo, Dr. Luis Bartolome, Dr. Olatz Zuloaga, Professor Juan Manuel Madariaga.

\section{References}

Campana SE. 1999. Chemistry and composition of fish otoliths: Pathways, mechanisms and applications. Marine Ecology Progress Series 188: 263-297. DOI: 10.3354/meps188263.

Campana SE. 2005. Otolith science entering the 21st century. Marine and Freshwater Research 56: 485-495. DOI: 10.1071/MF04147.

Elsdon T, Wells B, Campana SE, Gillanders B, Jones C, Limburg K, Secor DH, Thorrold SR, Walther BD. 2008. Otolith chemistry to describe movements and life-history parameters of fishes. Oceanography and Marine Biology: An Annual Review 46: 297-330. DOI: 10.1201/9781420065756.ch7.

Figueiredo MM, Gamelas JAF, Martins AG. 2012. Characterization of Bone and Bone-Based Graft Materials Using FTIR Spectroscopy. In: Infrared Spectroscopy - Life and Biomedical Sciences. InTech. DOI: 10.5772/36379.

Fleet M. 2015. Carbonated Hydroxyapatite. New York: Pan Stanford.

Ibrahim DM, Mostafa AA, Korowash SI. 2011. Chemical characterization of some substituted hydroxyapatites. Chemistry Central Journal 5: 74. DOI: 10.1186/1752-153X-5-74. 
355

356

357

358

359

360

361

362

363

364

365

366

367

368

369

370

371

372

373

374

375

376

377

378

379

380

381

382

383

384

385

386

387

388

389

390

391

392

393
Isaksson H, Turunen MJ, Rieppo L, Saarakkala S, Tamminen IS, Rieppo J, Kröger H, Jurvelin JS. 2010. Infrared Spectroscopy Indicates Altered Bone Turnover and Remodeling Activity in Renal Osteodystrophy. Journal of Bone and Mineral Research 25(6): 1360-1366. DOI: 10.1002/jbmr.10.

Koch PL. 2007. Isotopic Study of the biology of modern and Fossil Vertebrates. In: R. Michener and K. Lajtha, eds. Stable Isotopes in Ecology and Environmental Science, 2nd Edition. Boston, Massachusetts: Blackwell Publishing, 99-154. DOI: 10.1002/9780470691854.ch5.

Landi E, Celotti G, Logroscino G, Tampieri A. 2003. Carbonated hydroxyapatite as bone substitute. Journal of the European Ceramic Society 23(15): 2931-2937. DOI: 10.1016/S09552219(03)00304-2.

LeGeros RZ. 1981. Apatites in biological systems. Progress in Crystal Growth and Characterization 4: 1-45. DOI: 10.1016/0146-3535(81)90046-0.

LeGeros, RZ. 1991. Calcium Phosphates in Oral Biology and Medicine. Monographs in oral science 15: 1-201.

Lin S, Chang C, Iizuka Y, Tzeng W. 2007. Salinities, not diets, affect strontium/calcium ratios in otoliths of Anguilla japonica. Journal of Experimental Marine Biology and Ecology 341(2):

254-263. DOI: 10.1016/j.jembe.2006.10.025.

Liu Y, Ma L, Guo J, Dong G, Cong J, Ji Y, Ning J, Yang G, Wu K. 2018. Study of a new practical ESR dosimeter based on carbonated hydroxyapatite and its dosimetric properties. PLOS ONE 13(5): e0197953. DOI: 10.1371/journal.pone.0197953.

Lu HB, Campbell CT, Graham DJ, Ratner BD. 2000. Surface characterization of hydroxyapatite and related calcium phosphates by XPS and TOF-SIMS. Analytical Chemistry 72(13): 28862894. DOI: $10.1021 /$ ac990812h.

Luque PL, Rodriguez-Marin E, Landa J, Ruiz M, Quelle P, Macias D, Ortiz de Urbina JM. 2014. Direct ageing of Thunnus thynnus from the eastern Atlantic Ocean and western Mediterranean Sea using dorsal fin spines. Journal of Fish Biology 84: 1876-1903. DOI: 10.1111/jfb.12406.

Mathew M, Tagaki S. 2001. Structures of Biological Minerals in Dental Research. Journal of Research of National Institute of Standards and Technology 106(6): 1035-44. DOI: 10.6028/jres.106.054.

Peer] reviewing PDF | (2018:12:33216:2:1:NEW 15 May 2019) 
394 Matsunaga K, Murata H, Mizoguchi T, Nakahira A. 2010. Mechanism of incorporation of zinc 395 into hydroxyapatite. Acta Biomaterialia 6(6): 2289-2293. DOI: 10.1016/j.actbio.2009.11.029.

396

397

398

399

400

401

402

403

404

405

406

407

408

409

410

411

412

413

414

415

416

417

418

419

420

421

422

423

424

425

426

427

428

429

430

431

432

McMahon KW, Berumen ML, Thorrold SR. 2012. Linking habitat mosaics and connectivity in a coral reef seascape. Proceedings of the National Academy of Sciences 109: 15372-15376.

DOI:10.1073/pnas.1206378109.

Miller J. 2009. The effects of temperature and water concentration on the otolith incorporation of barium and manganese in black rockfish Sebastes melanops. Journal of Fish Biology 75 (1): 3960. DOI: $10.1111 /$ j.1095-8649.2009.02262.x.

Murugan R, Ramakrishna S, Panduranga RK. 2006. Nanoporous hydroxy-carbonate apatite scaffold made of natural bone. Materials Letters 60(23): 2844-2847. DOI:

10.1016/j.matlet.2006.01.104.

Patterson HM, Mcbride RS, Julien N. 2004. Population structure of red drum (Sciaenops ocellatus) as determined by otolith chemistry. Marine Biology 144: 855-862. DOI: 10.1007/s00227-003-1254-x.

Pellegrini M, Snoeck C. 2016. Comparing bioapatite carbonate pre-treatments for isotopic measurements: Part 2-Impact on carbon and oxygen isotope compositions. Chemical Geology 420: 88-96. DOI: 10.1016/j.chemgeo.2015.10.004.

Rey C, Combes C, Drouet C, Glimcher MJ. 2009. Bone mineral: Update on chemical composition and structure. Osteoporosis International 20: 1013-1021. DOI: 10.1007/s00198009-0860-y.

Rooker JR, Arrizabalaga H, Fraile I, Secor DH, Dettman DL, Abid N, Piero A, Deguara S, Karakulak FS, Kimoto Ai, Sakai O, Macias D, Neves Santos M. 2014. Crossing the line: migratory and homing behaviors of Atlantic bluefin tuna. Marine Ecology Progress Series 504: 265-276. DOI:10.3354/MEPS10781.

Santamaria N, Bello G, Pousis C, Vassallo-Agius R, de la Gándara F, Corriero A. 2015. Fin spine bone resorption in Atlantic bluefin tuna, Thunnus thynnus, and comparison between wild and captive-reared specimens. PLoS One10(3):e0121924. DOI:10.1371/journal.pone.0121924

Snoeck C, Pellegrini M. 2015. Comparing bioapatite carbonate pre-treatments for isotopic measurements: Part 1-Impact on structure and chemical composition. Chemical Geology 417: 394-403. DOI: 10.1016/j.chemgeo.2015.10.004. 
433 Termine JD, Lundy DR. 1973. Hydroxide and carbonate in rat bone mineral and its synthetic 434 analogues. Calcified Tissue International 13(1): 73-82. DOI: $\underline{10.1007 / B F 02015398}$.

435

436 Turunen MJ, Saarakkala S, Rieppo L, Helminen HJ, Jurvelin JS, Isaksson H. 2011. Comparison 437 between infrared and raman spectroscopic analysis of maturing rabbit cortical bone. Applied 438 Spectroscopy 65: 565-603. DOI: 10.1366/10-06193.

439

440 Tzadik OE, Curtis JS, Granneman JE, Kurth BN, Pusack TJ, Wallace AA, Hollander DJ, Peebles 441 EB, Stallingset CD. 2017. Chemical archives in fishes beyond otoliths: A review on the use of 442 other body parts as chronological recorders of microchemical constituents for expanding 443 interpretations of environmental, ecological, and life-history changes. Limnology and 444 Oceanography: Methods 15: 238-263. DOI: 10.1002/lom3.10153.

445

446

447

448

449

450

451

452

453

454

455

456

457

458

459

460

461

462
Ugarte A, Unceta N, Pecheyran C, Goicolea MA, Barrio RJ. 2011. Development of a matrix matching hydroxyapatite calibration standards for quantitative multi-element LA-ICP-MS analysis: Application to the dorsal spine of fish. Journal of Analytical Atomic Spectrometry 26: 1421-1427. DOI:10.1039/c1ja10037h

Walther B, Limburg K. 2012. The use of otolith chemistry to characterize diadromous migrations. Effects of preservatives and acidification on the stable isotope ratios $\left({ }^{15} \mathrm{~N}:{ }^{14} \mathrm{~N},{ }^{13} \mathrm{C}:{ }^{12}\right.$ C) of two species of marine animals. Journal of Fish Biology 81 (2): 796-825. DOI: 10.1111/j.1095-8649.2012.03371.

Wagner CD, Riggs WM, Davis LE, Moulder JFF, Muilenberg GE, Stickle WF. 1979. Data Interpretation. Handbook of X-ray Photoelectron Spectroscopy. Minnesota: Perkin-Elmer, Co. DOI: $10.1002 /$ sia.740030412.

Zymonas ND, McMahon TE. 2006. Effect of pelvic fin ray removal on the survival and growth of bull trout. North American Journal of Fisheries Management 26: 953-959. DOI:

10.1577/M05-119.1. 


\section{Table 1 (on next page)}

Wavenumber limits used in the curve fitting of the bands for Raman and FTIR spectra.

Intensities of Amide I, phosphate and carbonate as the spectral features used to estimate mineral/matrix ratio, carbonate/phosphate ratio and crystallinity. 
1 Table 1

2

Wavenumber limits $\left(\mathrm{cm}^{-1}\right)$

\begin{tabular}{ccc}
\hline Bands & Raman & FTIR \\
Amide I & $1590-1730$ & $1590-1730$ \\
Phosphate & $930-990$ & $900-1200$ \\
Carbonate & $1055-1090$ & $850-890$ \\
\hline
\end{tabular}

3 


\section{Table 2 (on next page)}

Spectral features of the detected elements in the different samples.

Binding energy (BE), full width at half maximum (FWHM), percentage of relative atomic concentration (\% At. rel.), total relative atomic percentage of the element (\% At. rel. Total). 
$1 \quad$ Table 2

\begin{tabular}{|c|c|c|c|c|c|c|}
\hline $\begin{array}{c}\text { Fin spine } \\
\text { sample }\end{array}$ & Element & Id. & BE (eV) & FWHM & \% At. rel. & $\begin{array}{c}\text { \% At. rel. } \\
\text { (Total) }\end{array}$ \\
\hline \multirow{7}{*}{ BFT1 } & \multirow{3}{*}{$\mathrm{C}(1 \mathrm{~s})$} & $\mathrm{C}-\mathrm{C}, \mathrm{C}-\mathrm{H}$ & 284.6 & 2.1 & 72.3 & \multirow{3}{*}{82.2} \\
\hline & & $\mathrm{C} 1 \mathrm{~s}$ & 286.9 & 2.1 & 5.7 & \\
\hline & & $\mathrm{C} 1 \mathrm{~s}$ & 288.5 & 2.1 & 4.3 & \\
\hline & $\mathrm{O}(1 \mathrm{~s})$ & $\mathrm{O} 1 \mathrm{~s}$ & 530.6 & 3.0 & 15.5 & 15.5 \\
\hline & \multirow[b]{2}{*}{$\mathrm{Ca}(2 \mathrm{p})$} & $\begin{array}{c}\mathrm{Ca} 2 \mathrm{p} \\
(3 / 2)\end{array}$ & 346.6 & 2.0 & 0.6 & \multirow[b]{2}{*}{0.9} \\
\hline & & $\begin{array}{l}\mathrm{Ca} 2 \mathrm{p} \\
(1 / 2)\end{array}$ & 350.0 & 2.0 & 0.3 & \\
\hline & $\mathrm{N}(1 \mathrm{~s})$ & $\mathrm{N} 1 \mathrm{~s}$ & 399.0 & 1.9 & 1.4 & 1.4 \\
\hline \multirow{5}{*}{ BFT2 } & \multirow{2}{*}{$\mathrm{C}(1 \mathrm{~s})$} & $\mathrm{C}-\mathrm{C}, \mathrm{C}-\mathrm{H}$ & 284.6 & 2.2 & 79.4 & \multirow{2}{*}{85.2} \\
\hline & & C 1s & 288.2 & 2.1 & 5.9 & \\
\hline & $\mathrm{O}(1 \mathrm{~s})$ & $\mathrm{O} 1 \mathrm{~s}$ & 531.8 & 2.9 & 12.5 & 12.5 \\
\hline & \multirow[b]{2}{*}{$\mathrm{Ca}(2 \mathrm{p})$} & $\begin{array}{c}\mathrm{Ca} 2 \mathrm{p} \\
(3 / 2)\end{array}$ & 347.3 & 2.2 & 1.6 & \multirow[b]{2}{*}{2.3} \\
\hline & & $\begin{array}{l}\mathrm{Ca} 2 \mathrm{p} \\
(1 / 2)\end{array}$ & 350.9 & 2.2 & 0.8 & \\
\hline \multirow{8}{*}{ BFT3 } & \multirow{2}{*}{$\mathrm{C}(1 \mathrm{~s})$} & $\mathrm{C}-\mathrm{C}, \mathrm{C}-\mathrm{H}$ & 284.6 & 2.7 & 48.7 & \multirow{2}{*}{57.9} \\
\hline & & $\mathrm{C} 1 \mathrm{~s}$ & 287.5 & 2.7 & 9.2 & \\
\hline & $\mathrm{O}(1 \mathrm{~s})$ & $\mathrm{O} 1 \mathrm{~s}$ & 530.8 & 2.8 & 24.6 & 24.6 \\
\hline & \multirow[b]{2}{*}{$\mathrm{Ca}(2 \mathrm{p})$} & $\begin{array}{c}\mathrm{Ca} 2 \mathrm{p} \\
(3 / 2)\end{array}$ & 346.6 & 2.3 & 4.0 & \multirow{2}{*}{5.9} \\
\hline & & $\begin{array}{l}\mathrm{Ca} 2 \mathrm{p} \\
(1 / 2)\end{array}$ & 350.2 & 2.4 & 2.0 & \\
\hline & $\mathrm{N}(1 \mathrm{~s})$ & $\mathrm{N} 1 \mathrm{~s}$ & 398.8 & 2.3 & 7.6 & 7.6 \\
\hline & \multirow{2}{*}{$P(2 p)$} & P $2 p(3 / 2)$ & 132.4 & 2.2 & 2.6 & \multirow{2}{*}{4.0} \\
\hline & & P $2 p(1 / 2)$ & 133.4 & 2.2 & 1.3 & \\
\hline \multirow{8}{*}{ BFT4 } & \multirow{2}{*}{$C(1 s)$} & $\mathrm{C}-\mathrm{C}, \mathrm{C}-\mathrm{H}$ & 284.6 & 2.6 & 54.0 & \multirow{2}{*}{65.0} \\
\hline & & $\mathrm{C} 1 \mathrm{~s}$ & 287.4 & 2.6 & 10.9 & \\
\hline & $\mathrm{O}(1 \mathrm{~s})$ & $\mathrm{O} 1 \mathrm{~s}$ & 530.6 & 3.0 & 23.1 & 23.1 \\
\hline & \multirow{2}{*}{$\mathrm{Ca}(2 \mathrm{p})$} & $\begin{array}{l}\mathrm{Ca} 2 \mathrm{p} \\
(3 / 2)\end{array}$ & 346.5 & 2.0 & 1.9 & \multirow{2}{*}{2.9} \\
\hline & & $\begin{array}{l}\mathrm{Ca} 2 \mathrm{p} \\
(1 / 2)\end{array}$ & 350.1 & 2.1 & 1.0 & \\
\hline & $\mathrm{N}(1 \mathrm{~s})$ & $\mathrm{N} 1 \mathrm{~s}$ & 399.0 & 2.3 & 7.1 & 7.1 \\
\hline & \multirow{2}{*}{$P(2 p)$} & P $2 p(3 / 2)$ & 133.0 & 2.1 & 1.3 & \multirow{2}{*}{1.9} \\
\hline & & P $2 p(1 / 2)$ & 134.0 & 2.1 & 0.6 & \\
\hline
\end{tabular}




\section{Table 3 (on next page)}

Band assignments for the Raman and FTIR spectra of bluefin tuna fin spine bone (BFT3). The baseline for each peak was linearly corrected using the same wavenumbers. 
$1 \quad$ Table 3

\begin{tabular}{|c|c|c|}
\hline Assigment & Raman band $\left(\mathrm{cm}^{-1}\right)$ & IR band $\left(\mathrm{cm}^{-1}\right)$ \\
\hline$v(\mathrm{O}-\mathrm{H}), v(\mathrm{~N}-\mathrm{H})$ & & 3434 \\
\hline$v(\mathrm{C}-\mathrm{H})$ & 2884,2936 & $2958,2923,2847$ \\
\hline Amide I & 1672 & 1660 \\
\hline Amide II & - & 1565 \\
\hline$\delta\left(\mathrm{CH}_{2}\right), \mathrm{CH}_{2}$ deformation & 1449 & 1454 \\
\hline$v_{3} \mathrm{CO}_{3}^{2-}$ & - & 1416 \\
\hline$\delta\left(\mathrm{CH}_{2}\right)$ & - & 1337 \\
\hline Amide III & 1241 & 1243 \\
\hline$v_{1} \mathrm{CO}_{3}^{2-} v_{3} \mathrm{PO}_{4}^{3-}$ & 1075 & 1110,1028 \\
\hline$v_{3} \mathrm{PO}_{4}{ }^{3-}$ & 1030 & - \\
\hline$v(\mathrm{C}-\mathrm{C})$ Phenylalanine & 1005 & - \\
\hline$v(\mathrm{C}-\mathrm{C})$ Collagen proline & 852 & - \\
\hline$v_{2} \mathrm{CO}_{3}^{2}$ & - & 872 \\
\hline $\begin{array}{c}v_{4} \text { antisymmetric bending } \\
(\mathrm{OPO})\end{array}$ & - & 602,560 \\
\hline$v_{4} \mathrm{PO}_{4}{ }^{3-}$ & 581 & 560 \\
\hline$v_{2} \mathrm{PO}_{4}{ }^{3-}$ & $430-450$ & - \\
\hline
\end{tabular}

2 


\section{Table 4 (on next page)}

Values of compositional parameters for each fin spine obtained from peak intensities in Raman and FTIR spectra 
Tablle 4

\begin{tabular}{cccccc}
\hline \multicolumn{5}{c}{ Parameters } \\
\hline Technique & $\begin{array}{c}\text { Sample } \\
\text { ID }\end{array}$ & $\begin{array}{c}\text { Body } \\
\text { length }\end{array}$ & $\begin{array}{c}\text { Mineral/Matrix } \\
\text { (intensities) }\end{array}$ & $\begin{array}{c}\text { Carbonate/Phosphate } \\
\text { (intensities) }\end{array}$ & Crystallinity \\
\hline Raman & BFT1 & $128 \mathrm{~cm}$ & 3,973 & 0,102 & 0,058 \\
& BFT2 & $114 \mathrm{~cm}$ & 7,025 & 0,093 & 0,061 \\
& BFT4 & $101 \mathrm{~cm}$ & 4,700 & 0,108 & 0,056 \\
mean \pm SD & & & $5,93 \pm 1,594$ & $0,101 \pm 0,008$ & $0,058 \pm 0,003$ \\
\hline FTIR & BFT1 & $128 \mathrm{~cm}$ & 2,945 & 0,077 & \\
& BFT4 & $101 \mathrm{~cm}$ & 2,171 & 0,079 & \\
& BFT3 & $81 \mathrm{~cm}$ & 1,845 & 0,126 & \\
mean \pm SD & & & $2,32 \pm 0,565$ & $0,094 \pm 0,028$ & \\
\hline
\end{tabular}

2 
Figure 1

Description of the sectioning axis location

a) an anterior view of the condyle base and the location of Dmax, which is measured along the imaginary line below the hollows, b) the lateral view of the condyle base with the location of the 1.5 cutting axis at $1.5 \mathrm{Dmax}$ from the same imaginary line.

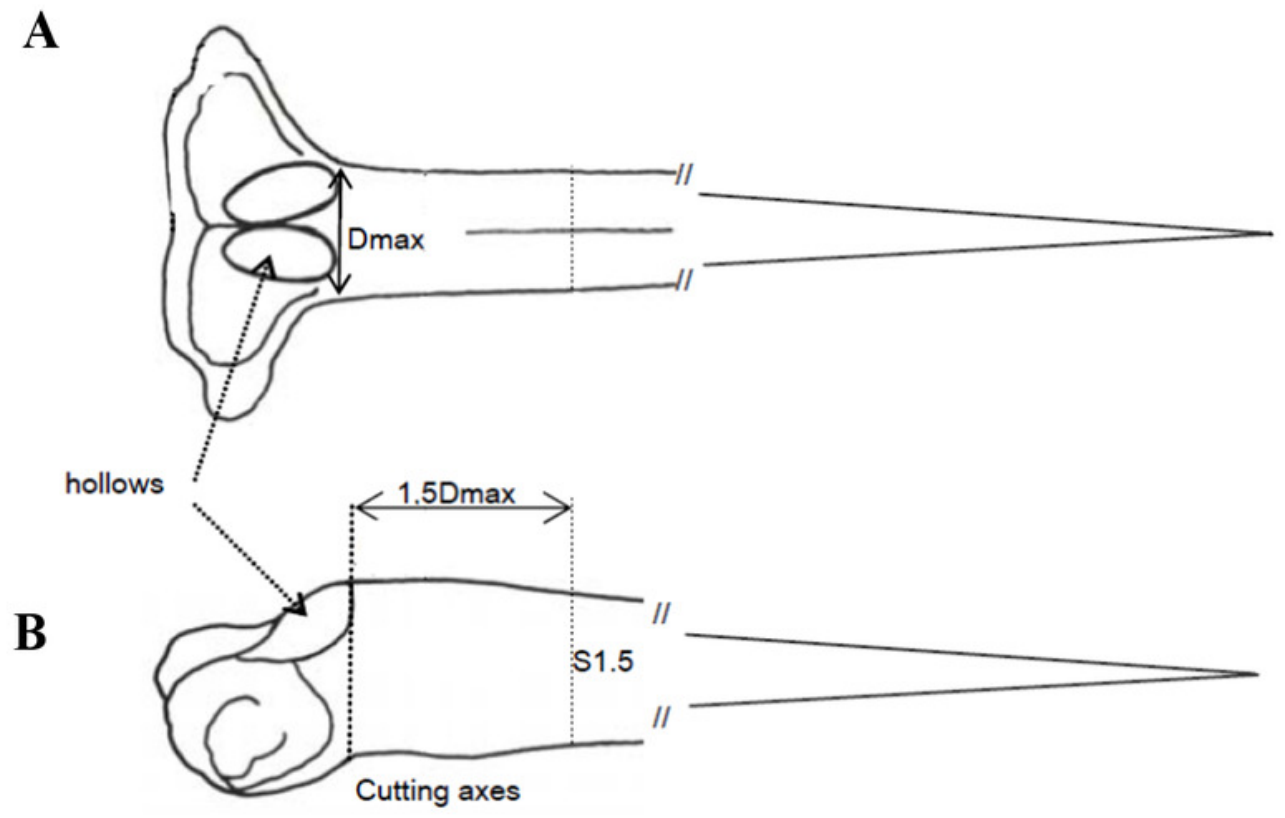


Figure 2

XPS survey spectrum of fin spine (BFT3) showing signals for $\mathrm{Ca}, \mathrm{P}, \mathrm{O}$ (three compositional elements of calcium phosphate "hydroxyapatite").

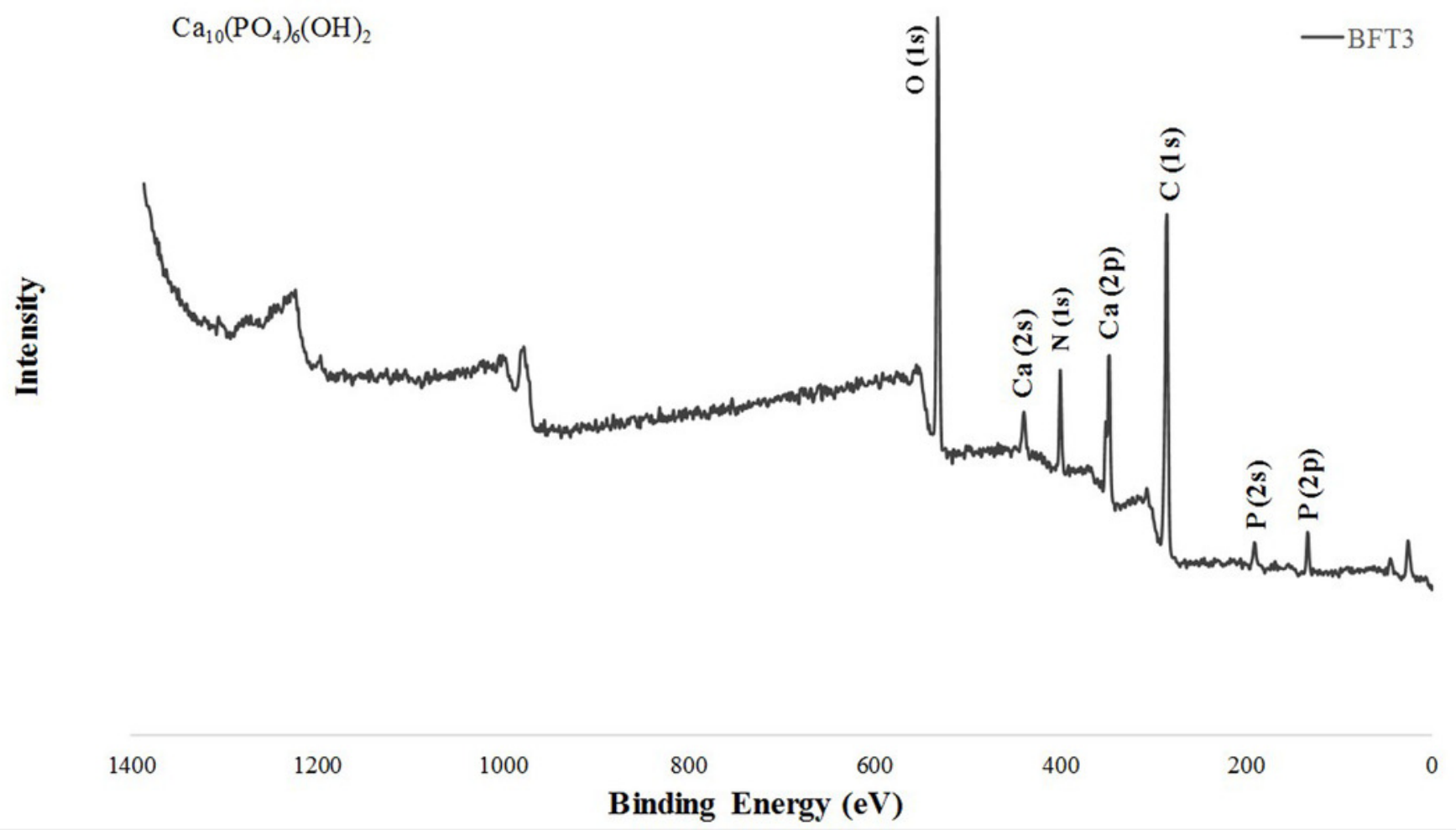


Figure 3

Raman spectra of bluefin fin spine bone and human bone measured in the same instrumental conditions.

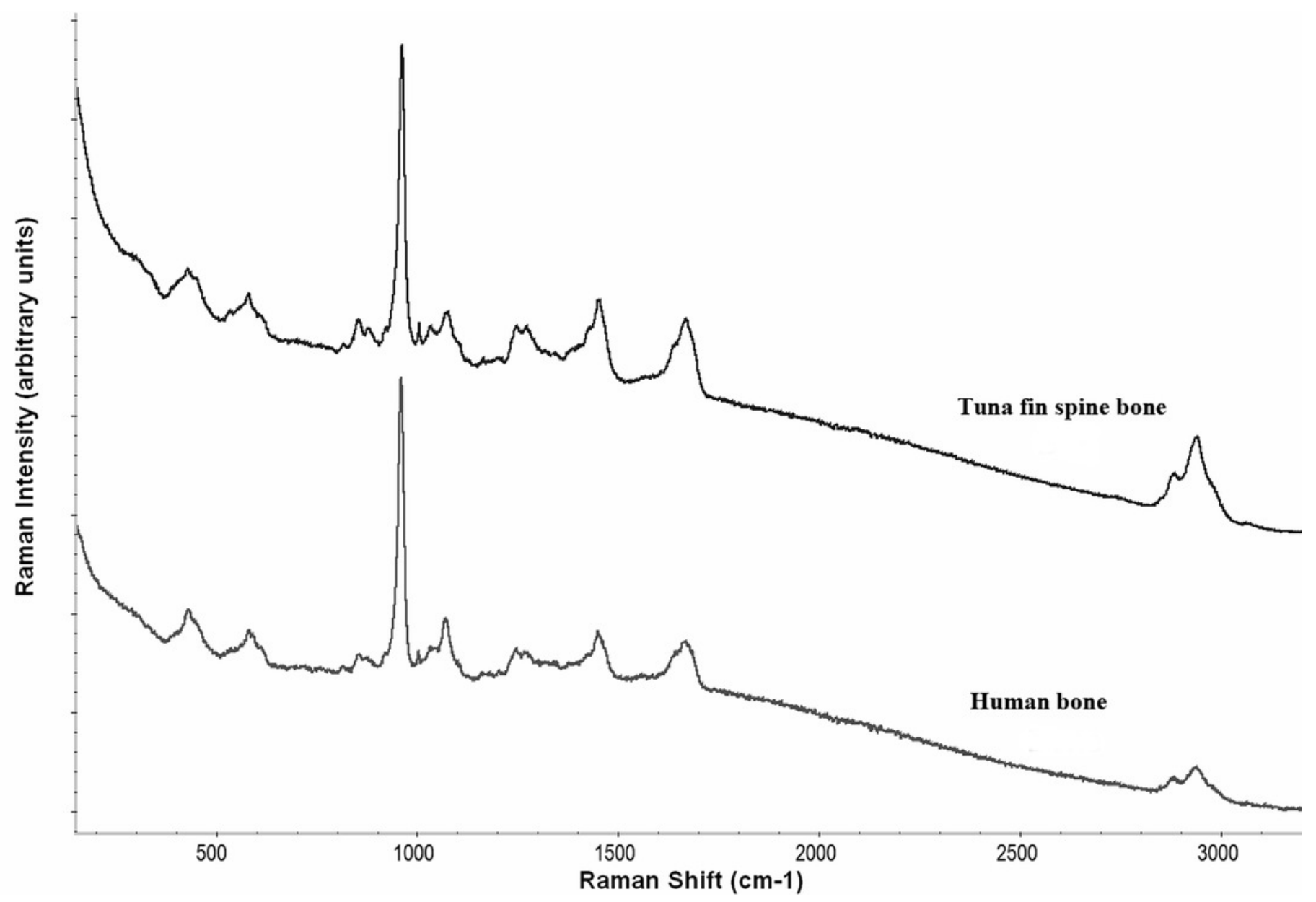


Figure 4

Spectral regions in the FTIR spectrum of bluefin tuna fin spine bone related to Type B carbonate substitution

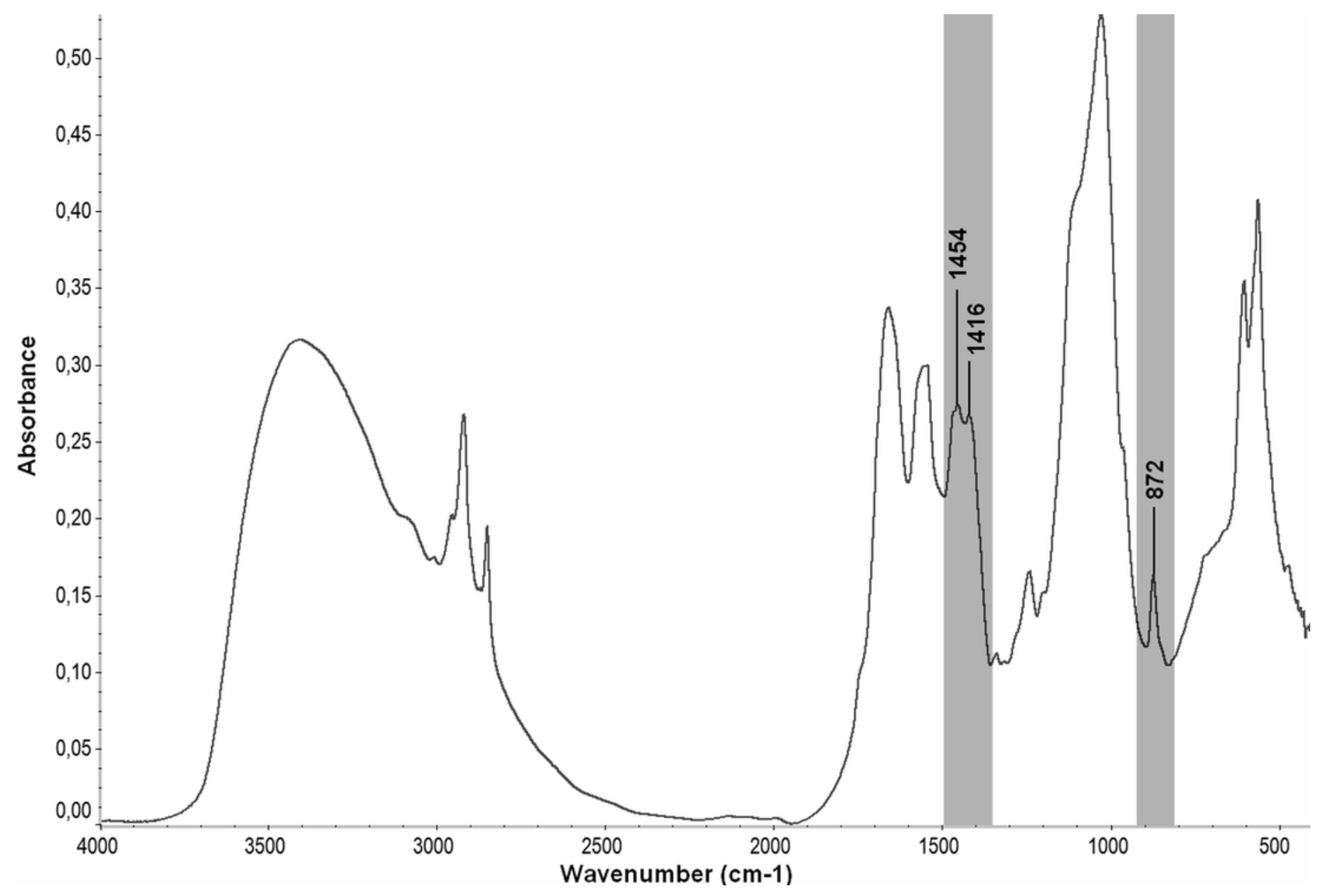

